\title{
'NO CONDOM, NO SEX': EASY TO SAY, BUT NOT POSSIBLE FOR all South African women
}

Author:

Johanna E. Maree ${ }^{1}$

\section{Affiliation:}

${ }^{1}$ Adelaide Tambo School of Nursing Science, Tshwane University of Technology, South Africa

\section{Correspondence to: Johanna Maree}

email:

mareeje@tut.ac.za

\section{Postal address:}

Adelaide Tambo School of Nursing Science, Private Bag X680, Pretoria 0001, South Africa

\section{Keywords:}

cancer prevention strategies; condom use; fear of sexually transmitted infections; risk perception; self-protection in sexual relationships

\section{Dates:}

Received: 13 Oct. 2009

Accepted: 06 June 2010

Published: 01 Nov. 2010

How to cite this article:

Maree, J.E., 2010, 'No condom, no sex': Easy to say, but not possible for all South African women', Health SA Gesondheid 15(1), Art. \#506, 8 pages. DOI: $10.4102 /$ hsag. v15i1.506

This article is available at: http:/ / www.hsag.co.za

(C) 2010. The Authors. Licensee: OpenJournals Publishing. This work is licensed under the Creative Commons Attribution License.

\section{ABSTRACT}

Cervical cancer is the most common cancer in South African women. The human papillomavirus (HPV) is the biggest risk factor for developing this cancer. However, condom use protects against HPV transmission. The purpose of the study was to investigate whether Black women living in Tshwane, South Africa, were able to protect themselves against cervical cancer by insisting on condom use. The study was exploratory, qualitative and contextual, and a convenience snowball sampling method was used. The sample size was determined through data saturation $(n=20)$. Selfreported data were gathered by means of interviews, and analysed using Tesch's approach. Four themes emerged, (1) knowledge of cervical cancer, (2) sexual behaviour, (3) social problems and (4) emotions. The study provided evidence that women were not able to protect themselves from cervical cancer by insisting on condom use. Women lacked knowledge of cervical cancer and did not associate condom use with self-protection against this disease. Most of their sex partners refused to use condoms. Poverty, physical abuse, helplessness and fear prevented women from insisting on the use of condoms. Primary prevention strategies should focus on empowering women to protect themselves from cervical cancer and not leave this important issue to someone who might refuse it.

\section{OPSOMMING}

Servikskarsinoom is die mees algemene kanker in Suid-Afrikaanse vroue. Die menslike papiloom virus (MPV) is die grootse oorsaak van hierdie kanker. Oordraging van die virus kan egter met kondoomgebruik voorkom word. Die doel van die studie was om te bepaal of Swart vroue woonagtig in Tshwane, Suid-Afrika, hulself teen die virus kan beskerm deur op kondoomgebruik aan te dring. Die studie was eksploratief, kwalitatief en kontekstueel en 'n gerieflikheids sneeubal metode het die steekproef gerig. Die steekproefgrootte is deur dataversadiging bepaal $(n=20)$. Data is ingesamel deur middel van onderhoude en die data is met behulp van Tesch se metode geanaliseer. Vier temas is geïdentifiseer, (1) kennis van servikskarsinoom, (2) seksuele gedrag, (3) sosiale probleme en (4) emosies. Die studie het bevind dat vroue hulle nie self teen servikskarsinoom kan beskerm deur op kondome aan te dring nie. Kennis van die siekte was so gebrekkig dat vroue nie kondoomgebruik met servikskarsinoom vereenselwig het nie. Die meeste van hul seksmaats het geweier om kondome te gebruik. Armmoede, fisiese geweld, hulpeloosheid en vrees het vroue weerhou om op die gebruik van kondome aan te dring. Primêre voorkomingstrategië behoort op selfbemagtiging van vroue te konsentreer. Dit sal voorkom dat vroue van mans, wat hulle die reg kan weier, afhanklik is vir beskerming teen servikskarsinoom.

\section{INTRODUCTION}

Various neoplastic diseases are caused by viruses that are sexually transmitted, and these include cervical, vaginal and vulvar cancer, and leukaemia. Neoplastic viruses give rise to up to 500000 new malignancies annually and in some undeveloped countries, cause as much as 50\% of all cancers (Epstein 2005:2595). As in all sub-Saharan African countries, in South Africa, cancer of the cervix is the most common cancer in women (World Health Organization and International Union Against Cancer 2005:5; South African Medical Research Council 2008). It is a well-known fact that the human papillomavirus (HPV) is the biggest risk factor for developing cervical cancer (Cothran \& White 2002:306) and it is estimated that 105 million women worldwide would at least once in their lifetime have an HPV-16 and an HPV-18 infection, the most common oncogenic type of HPV found in women with cervical cancer (Burchell et al. 2006:S52). Neoplastic viruses, like all other sexually transmitted infections, are transmitted by unsafe sex. Sex can be described as any sexual activity involving contact with body fluids (Epstein 2005:2595). According to Schiffman et al. (2007:892), anogenital HPV is transmitted not only by sexual intercourse (mucosa-to-mucosa transmission) but also by skin-to-skin contact.

Condom use is seen as the only barrier form of contraceptive that protects against transmission of the HPV effectively (Frega et al. 2003:131). According to Epstein (2005:2597), latex condoms are impermeable to most viruses and the use of condoms would decrease the risk for cervical cancer. For Epstein (2005:2598), condoms play such a major role in the primary prevention of HPV-dependent neoplasia that he advocates a sociocultural norm of 'No condom, no sex'. The Cancer Association of South Africa (CANSA 2005) also warns that women have a greater risk of cervical cancer if their sexual debut was at the young age of 15 and younger, and if a woman has many sex partners.

Primary cancer prevention includes measures to improve health practices (Mahon 2009). Using condoms is one of the health practices that may assist with the prevention of sexually transmitted cancers (Frega et al. 2003:131). It is not known if Black women living in Tshwane would be able to achieve this specific primary cancer prevention objective, as no studies are available to guide us, and our results.

\section{PROBLEM STATEMENT}

Not all women have control over their social position and sexuality, as many women in developing countries are subservient to men, are uninformed and disempowered (Denny, Quinn \& 
Sankaranarayanan 2006:S3/72). According to Okin (1998:36), women who are struggling against culturally and religiously imposed violations of women's rights have expressed the need to be heard. To guide nursing practice with regard to the primary prevention of cervical cancer, the nurse needs to listen carefully to women to understand if they can protect themselves against contracting the HP virus. The research question for the study arose as to whether it is possible for Black women living in Tshwane, South Africa, to protect themselves against cervical cancer, by insisting on condom use.

\section{THEORETICAL FOUNDATION}

The theoretical foundation selected for this study was Parse's Theory of Human Becoming (Mitchell 2006). According to Parse (1992), the goal of nursing practice is '... quality of life as described by the person and the family'. Quality of life is considered to be the 'whatness' that makes life what it is and consists of the meanings, feelings and thoughts of life experiences (Mitchell 2006:442). The Theory of Human Becoming assumes that individuals are free agents who are open, choose freely, are responsible for the choices made and give meaning to situations. Health is seen as a personal commitment (Parse 1990) and nurses therefore do not have control over people or their health choices (Mitchell 2006:431). The nurse enters the world of the person with a strong knowledge base, openness and self-giving (Parse 1990:139, 1992:39; Mitchell 2006:443) and approaches the person and the family as a "nurturing gardener rather than a "fix-it" mechanic' (Parse 1990:139). In true presence, the nurse invites the patient to talk about the meaning of the situation. In this process of articulation in the presence of the nurse, insights are clarified, discoveries are made and change is proposed as the individuals see themselves and their situations in a new light (Mitchell 2006:443; Parse 1992:39, 1990:139).

Believing that individuals live their own way which is alike with, and different from, the way others live (Parse 1990:40), the researcher invited the participants to share their reality with regard to self-protection in their sexual relationships. Chimbiri (2007:1113) states that 'initiating a discussion of condom use for preventing infection in marriage is like bringing an intruder into the domestic space.' This was not the experience of the researcher, and Parses' Theory of Human Becoming (Mitchell 2006:431-460) led towards approaching the participants and this sensitive issue with openness. The researcher did not know the participants' meaning of condom use and trusted it would unfold in the nurse-person articulation process. Applying Parse's Theory of Human Becoming enabled the participants, despite the researcher being a White South African woman, to speak openly. The researcher, who is an oncology nurse and is completely aware of the importance of condom use to protect women against cervical cancer, did not offer professional opinions and advice on the importance of condom-use based on her own lived value system (Parse 1992:40). The researcher stayed in true presence with the participants while they described their struggles, up-and-downs, moments of joy and the unevenness of living 'in the now'. The researcher did not try to calm uneven rhythms but moved with the flow of the rhythms and recognised the struggles of the situation (Parse 1992:40).

\section{RESEARCH DESIGN AND METHODS}

\section{Research context}

Gauteng is the smallest province of South Africa and has a population of 8.8 million people, approximately $20 \%$ of the total South African population. More than $60 \%$ of the research and development of South Africa takes place in Gauteng, which also has the hightest per capita income in the country. The context for the study was Tshwane, a municipal area in Gauteng that hosts a population of approximately 2 million. The majority of the Tshwane population $(65 \%)$ is under the age of 35 years and a little less than $50 \%$ has some secondary education. Unemployment is high $(20.4 \%)$ and $58.8 \%$ has no source of income (Gauteng Tourism Authority, SA n.d.).

\section{Research design}

The research design for this study was exploratory, qualitative and contextual. A qualitative research approach was used for describing life experiences and giving meaning to these experiences (Burns \& Grove 2005:747). Using an exploratory design enabled the researcher to gain new insight and increase knowledge of the research problem without comparing it to other phenomena (Welman \& Kruger 1999). The study was contextual and therefore the results are only valid for the situation in which the study was done (LoBiondo-Wood \& Harber 2006:561).

\section{Population}

The target population for this study was all women living in Tshwane who were from an African cultural group, older than 18 years, currently or previously involved in a sexual relationship with a male partner, able to understand and converse in English and willing to participate in the study. Burns and Grove (2005:342) describe a target population as all the individuals who meet the sampling criteria. The accessible population from which the sample was obtained (Burns \& Grove 2005:342) included all women that met the target population criteria and worked at an institution of higher learning in Tshwane.

A convenience (Burns \& Grove 2005) snowball sampling method (LoBiondo-Wood \& Harber 2006) was used. Snowball sampling takes advantage of social networks (LoBiondo-Wood \& Harber 2006) and the first woman recruited for the study recruited the others. Twenty participants were interviewed $(n=20)$.

\section{Data gathering}

Data were gathered by means of self-reports using an interview consisting of two parts. Pierce, in Talbot (1995:592), emphasises that self-report methods are very effective when the purpose of the study is to obtain information about attitudes, knowledge, feelings and other information that cannot be easily observed or measured physiologically. During the first part of the interview, demographic data were collected by means of a questionnaire. During the second part of the interview, data regarding cervical cancer, condom use and the meanings, feelings and thoughts of what makes life what it is (Mitchell 2006:442) were collected. An interview schedule was used to assist in keeping the participants on track.

Women who agreed to participate were interviewed in private in the researcher's office during their lunch break, with only the researcher present, from August 2008 to October 2008. The researcher created a trusting relationship before the interviews were conducted. A voice recorder was used to record the interviews and the researcher also made notes. Although an hour was planned for the interview, the time was not limited to one hour, in order to allow the participants enough time to share their experiences. Interviews were transcribed on the day of the interview and saturation of data was achieved after the first 18 interviews.

\section{Data analysis}

Open coding, using Tesch's approach (Creswell 1994:55), was used to analyse the data. Open coding can be described as the process of breaking down and conceptualising data (Holloway \& Wheeler 2002:158). The data in the voice recordings were transcribed verbatim, each transcript was read thoroughly and underlying meanings which came to mind were written down. A list of topics that occurred was made and similar topics grouped together. The most descriptive wording for the grouped topics was used for categories, and the assembled data in each category was again analysed to finalise the themes and categories. 
TABLE

Strategies and criteria to enhance trustworthiness

\begin{tabular}{|c|c|}
\hline Strategy & Criteria \\
\hline Credibility & $\begin{array}{l}\text { Prolonged engagement } \\
\text { Reflexivity } \\
\text { Triangulation } \\
\text { Member checking } \\
\text { Peer examination }\end{array}$ \\
\hline Transferability & $\begin{array}{l}\text { Nominated sample } \\
\text { Dense description }\end{array}$ \\
\hline Dependability & $\begin{array}{l}\text { Description of research methods } \\
\text { Code-recode procedure }\end{array}$ \\
\hline Confirmability & $\begin{array}{l}\text { Member checking } \\
\text { Reflexivity }\end{array}$ \\
\hline
\end{tabular}

TABLE 2

General characteristics of participants $(n=20)$

\begin{tabular}{|c|c|}
\hline & $n$ \\
\hline \multicolumn{2}{|l|}{ Cultural group } \\
\hline Tswana & 4 \\
\hline Tsonga & 5 \\
\hline Ndebele & 1 \\
\hline Northern Sotho & 2 \\
\hline Zulu & 4 \\
\hline Pedi & 3 \\
\hline Shangaan & 1 \\
\hline \multicolumn{2}{|l|}{ Age (years) } \\
\hline $20-29$ & 1 \\
\hline $30-39$ & 7 \\
\hline $40-49$ & 8 \\
\hline $50-59$ & 4 \\
\hline \multicolumn{2}{|l|}{ Marital status } \\
\hline Unmarried & 10 \\
\hline Married (civil, religious or traditional) & 10 \\
\hline \multicolumn{2}{|l|}{ Education level } \\
\hline Grade $1-7$ & 8 \\
\hline Grade $8-10$ & 6 \\
\hline Grade $11-12$ & 6 \\
\hline \multicolumn{2}{|l|}{ Monthly income } \\
\hline R801 - R1600 & 5 \\
\hline R1601 - R3200 & 13 \\
\hline R3201 - R6400 & 2 \\
\hline
\end{tabular}

\section{RESULTS AND DISCUSSION}

Except for the demographic data, four themes emerged from the data, (1) knowledge of cervical cancer, (2) sexual behaviour, (3) social problems and (4) emotions. Narratives of 16 women are reflected in the results; pseudonyms are used. The general characteristics of the women are presented in Table 2.

Marriage was not found to be a prerequisite for women to be in a sexual relationship. This is, however, not exceptional as Denis (2006:5), reflecting on marriage in contemporary South Africa, states that the percentage of South African women between the ages of 15 and 49 years who were married during the period 1995-1999 was significantly less than 30\%. Abdool-Karim (2001:195) also found that only a 'few' sexually active women living in KwaZulu-Natal were married. Social class, rather than race or culture, results in Black people not getting married in South Africa. For many Black people, bride wealth ('lobola') which predicates marriage is simply not affordable because they are too poor (Denis 2006:5). However, in sub-Saharan Africa, even monogamous marriages remain potentially polygamous, as the nature of the marriage transaction gives men exclusive sexual rights to their partners. The same does not apply to women, and married women have an increased risk of being infected with a sexually transmitted infection due to their husband's extra-marital affairs (Hattori \& Dodoo 2007:1068).

\section{Knowledge of cervical cancer}

Only one of the participants knew of the existence of cervical cancer. The remainder indicated that they had never heard of cervical cancer. One participant commented:

'That cancer, I have never heard of it ...'

(Annah, 49)

After explaining that cervical cancer is cancer of the 'mouth of the womb' or pophelo ('uterus' in Setswana), is caused by a virus or a 'very small germ' and can 'work' like a sexually transmitted infection, nine participants indicated that they knew what a sexually transmitted infection was. However, 16 participants mentioned HIV/AIDS and nine mentioned gonorrhoea (also known as 'drop' ) as sexually transmitted infections, in so doing, indicating a lack of, or incorrect knowledge about them. The HP virus was not mentioned at all.

The following illustrated the women's lack of knowledge:

'I have never heard of a disease that one can give another by means of sex. I have heard of AIDS but I do not know how you become ill.'

(Beauty, 57)

'Drop - that is that sickness of the man. It makes yellow and drops ...'

(Annah, 49)

'I hear if you go to the toilet you will get the AIDS and also from the TB.

(Lily, 56)

One participant linked the number of sex partners to infections:

'When a husband gets more girlfriends, you get more infection. The infection comes slow, slow, slow and next time it can cause TB.'

(Prudence, 44)

Various studies conducted in different areas in South Africa also illustrated women's lack of knowledge of cervical cancer. In a study conducted by Heysteck et al. (1995:1180) at a day hospital in a township in Tshwane, it was found that only $2 \%$ of female patients had good knowledge of cervical cancer, whilst 93\% were found to be ignorant. Maree and Wright (2007:63) also reported that only $45 \%$ of the women in their study conducted in another township in Tshwane were aware of cervical cancer. In an investigation done in KwaZulu-Natal, Pillay (2002:103) found that almost $20 \%$ of the women had not heard of cervical cancer. With regard to knowledge of sexually transmitted infections, Hawken et al. (2002), Stark and Hope (2007) and Mnbaga et al. (2008), investigated women's knowledge of sexually transmitted infections and found it to be, as stated by Hawken et al. (2002), 'alarmingly low'.

Of the nine women who indicated they knew what a sexually transmitted infection was, six were of the opinion that their partners also knew what a sexually transmitted infection was, as they had discussed the matter with their partners.

To motivate that her sex partner knew what a sexually transmitted infection was, one of the women responded:

'Last time when I was pregnant, he went with me to hospital and they tested me. Then they told him about it.

(Rosie, 30)

One of the two women who said that their sex partner did not have any knowledge of sexually transmitted infections expressed herself clearly:

'No, he does not know because our people do not want to listen. When we make that sex, he can't accept that condom.'

(Thembi, 39)

In 1997, Gomo et al. (1997:192) reported a higher level of knowledge of sexually transmitted infections in men than in women living in a farming community in Zimbabwe. However, 
Mason (2005:266) found that men living in north-western England had limited knowledge of sexually transmitted infections. Verhoeven et al. (2006:391) found Belgian men's awareness of HPV, its sexually transmitted nature and its link to cervical cancer to be low, with male sexual behaviour being perceived as relatively unimportant in the context of cervical cancer. Makua (2008:111-112) found that South African men living in a district in north-western Tshwane had no knowledge of cervical cancer and had also never mentioned that HPV transmitted by men was a risk factor for the development of cervical cancer.

\section{Sexual behaviour}

Of the participants, 16 reported having a sexual relationship. The partners of the four who were not in a sexual relationship had died. Lack of a current sex partner was explained as:

'My husband was very, very cross when I asked him to use a condom. He died ... That is why I am scared of a man.'

One woman reported that she had two sex partners - her husband and her boyfriend - and described her situation as follows:

'I have two sex partners, my husband and a boyfriend. Only two not three ... My husband does not know ...'

Despite the fact that multiple, concurrent sexual relationships appear to be an acceptable norm in many South African communities (iolHIVAids.co.za site 2008), only one woman had two concurrent sexual partners. Concurrent sexual behaviour does not appear to be a tendency in women. Although Carter et al. (2007:822) reported a concurrent sexual relationship in $23 \%$ of their population sample living in Botswana, Senn et al. (2009:343) found that such concurrency was associated with being male, using alcohol and other drugs, not cohabiting with a partner and thinking that the steady partner was monogamous. Non-religious people were also more likely to have a concurrent sexual relationship (Senn et al. 2009:822) and only $26 \%$ of persons who had a partner having a concurrent sexual relationship were aware of it (Drumright, Gorbach \& Holmes 2004:437).

The use of condoms was a sensitive issue. It is true that numerous African cultures forbid women to suggest safer sexual practices (Adesoji 2005) and women also believe they have no right to such practices (Abdool-Karim 2001). According to Brandhorst, Krumboltz and Shapiro (1979:416) women often display the feminine assets of nurturance and empathy, however their socialisation does not give them permission to apply the same behaviours to themselves. Women who ask their partners to use a condom are usually viewed in a very negative light and often seen as being sexually available and ready for sex, nonconformist and overly dominant (Maharaj 2001:158). It also seems as if male rights to sexual pleasure violate the right of women to health (Oriel 2005:399) by protecting themselves from HPV and cervical cancer.

Despite possible cultural barriers, 14 participants asked their partners to use a condom, and five did not ask their partners. One did not ask her partner, but took condoms from the clinic and left it to her husband to ask the questions. Of the five women that did not ask their partner to use a condom, only three said that they trusted their partners and therefore did not deem it necessary to ask.

Reasons for not asking were explained as follows:

'I have never asked him to use a condom ... I will never use a condom because we are both faithful.'

(Naomi, 35)

I never asked him to use a condom, because I trusted him... we now use condoms because we are both positive. He was my only partner for 15 years ...

(Helen, 38)

Trusting the partner is associated with lower levels of safer sex (Paranjape et al. 2006:90) and investigators such as Agha et al. (2002), and Abdullah et al. (2002:180) found that trusting the partner was predominantly the reason for not using condoms. Maharaj (2001:156) agrees, saying that for both men and women, condom use is commonly seen as offensive and suitable for casual relationships. As condoms suggest lack of trust and infidelity, they are perceived not to be suitable for stable, ongoing relationships, let alone in a marital relationship, and raising the issue of condom use creates tension, anger and even confrontation.

Another reason for not asking their partner to use a condom was fear:

'I am too scared to ask him to use a condom because I am scared that he will beat me. If I say that thing he will beat me. He will say why do you say that thing?'

(Prudence, 44)

In a study describing obstacles in negotiating dual sexual protection, Maharaj (2001:156) found that it is expected of the woman to convince her partner to use a condom when she fears being infected. This does not appear possible in abusive relationships, as Oriel (2005:395) observes that women in situations of domestic violence sometimes give in to sex simply because they are too afraid for their lives to say 'no'.

TABLE 3

Women's narratives on the use of a condom

\begin{tabular}{|c|c|}
\hline Refusal to use a condom & Women's feelings and reactions \\
\hline 'He refused the condom. He said the condom is not right.' & $\begin{array}{l}\text { 'I don't know why he does that. I cannot insist... he will think that I have someone else. We } \\
\text { will fight again if I insist... we do not only fight with words... he hits me with the fist when we } \\
\text { fight.' (Thembi, 39) }\end{array}$ \\
\hline $\begin{array}{l}\text { 'First he refused to use the condom. He says that he does not work with those things. He } \\
\text { was cross, but he came right.' }\end{array}$ & 'I want him to use the condom but not every day.' (Sarah, 54) \\
\hline $\begin{array}{l}\text { 'I asked him several times and he said no, I do not want to use this. He said that he kept it } \\
\text { so that he is my boyfriend and I am his girlfriend.' }\end{array}$ & 'I trusted him that he did not have other girlfriends.' (Ruth, 28) \\
\hline $\begin{array}{l}\text { 'He refused and was very cross. He said you are my wife... I am your husband... I took } \\
\text { out lobola for you. You have another man that you like because you will have sex with him } \\
\text { without a condom.' }\end{array}$ & 'We fought ... and he beats me when we fight... I asked him several times.' (Lerato, 48 ) \\
\hline $\begin{array}{l}\text { 'I asked him a long time ago but he does not want to... He was very, very cross. He said } \\
\text { we have a marriage of } 33 \text { years and for so long we did not used a condom. Why must we } \\
\text { use it now?' }\end{array}$ & $\begin{array}{l}\text { 'I said to him it does not matter. I cannot walk with you and see what you are doing... why } \\
\text { after I slept with you my back feels so warm, warm, warm, warm and if I pee, my pee is so } \\
\text { red and warm? Last Monday was the last time that we had sex without a condom. I told him } \\
\text { - no sex if you do not use a condom. If you come to me and don't use a condom, I will tell } \\
\text { the police that you raped me.' (Ntombi, 53) }\end{array}$ \\
\hline $\begin{array}{l}\text { 'Our husbands say that they do not want that thing. He does not want the condom and } \\
\text { says that he can do better if he has to use a condom.' }\end{array}$ & $\begin{array}{l}\text { 'I said to him that I want a condom, he says he does not want a condom ... He beats me. I } \\
\text { stopped asking him to use a condom ...' (Beauty, } 57)\end{array}$ \\
\hline $\begin{array}{l}\text { 'I asked him to use a condom. First he was not very happy with it and we had a fight about } \\
\text { it. He said all this time you did not ask me and now... maybe I want to sleep all over ....' }\end{array}$ & $\begin{array}{l}\text { 'I told him that maybe we can go to the doctor and see if we have a disease or what. He } \\
\text { was not OK with it but I do not know what made him change his mind.' (Masego, 20) }\end{array}$ \\
\hline $\begin{array}{l}\text { 'I took some condoms... he asked what is this? He asked do you have a new boyfriend. } \\
\text { He said that he cannot use this....' }\end{array}$ & $\begin{array}{l}\text { 'You must just cook and eat and do what he says because you do not know what he would } \\
\text { do.' (Prudence, 44) }\end{array}$ \\
\hline
\end{tabular}


Of the participants, 12 reported that their partners refused to use a condom and three were even beaten because they asked their partners to do so. Two partners changed their minds after refusing initially; it is not clear what effected the mind-change. However, Williamson et al. (2006:89) found in their study that women's insistence, refusal to have sex, persuasion and family planning reasons persuaded their partner to agree. Narratives of women indicating refusal of condom use by their partners and their feelings and reactions are reflected in Table 3.

Despite being asked, the participants' partners refused to use condoms and reacted by saying that they were faithful, threatened to take another partner that would have sex without a condom, accused the female partner of infidelity, and even beat her. Various reasons for refusing condom use have been reported previously. Except for trusting the partner, other reasons preventing men from using condoms are (1) a preference for flesh-to-flesh contact (Maharaj 2001:156; Singer et al. 2006:2018), (2) an interruption of sexual activity, (3) discomfort (Maharaj 2001:156; Agha et al. 2002:180) and (4) reduction of sensation (Abdullah et al. 2002:183; Randolph et al. 2007:844). However, it appears that the real problem with condom use is the fact that is it not used (Steiner, Cates \& Warner 1999:450), which Oriel (2005:398) relates to the maintenance of masculinity. Men refusing to use condoms and still having sexual intercourse violate the human rights of women, that is, the right to health, bodily integrity and even the right to life (Oriel 2005:399).

According to Albertyn (2003), South African women have little say in their sexual relations because of cultural norms and the patriarchal system. Gavey, McPhillips and Doherty (2001) outline anecdotal reports that suggest that South African women have been beaten because they tried to negotiate safer sex. This study provides evidence that corroborates such reports. According to Maharaj and Cleland (2005), there is nothing a woman can do if her husband refuses to use a condom. For some of the women, not being able to do anything was indeed a reality: Participant Lerato reported that her husband refused to use a condom because he had paid 'lobola' for her. According to Maharaj (2001:157) paying 'lobola' empowers men to feel that they can dictate the conditions under which sexual acts can occur and physical violence is even used to force a woman to submit in their sexual relationship.

Four of the respondents' partners agreed to use a condom. In Table 4, narratives of partners who were prepared to use a condom are reflected.

Woodsong and Koo (1999:575) reported positive associations with condom use: Men using condoms are seen to care about themselves and their partner and are thought to show respect for the woman. Men also accept condoms to please their partner, protect her, himself and their children, and even to continue having other partners (Williamson et al. 2006:89). A woman who prefers a condom is seen as having a good self-esteem (Woodsong \& Koo 1999:575).

\section{Social problems}

Domestic violence was part of the lives of nine women. Except for violence that was mentioned as part of condom use, five reported other incidences. Domestic violence was described as follows:

'He beat me many, many times ... he would take the blankets off me, put it on the ground and beat me."

(Lerato, 48$)$
'When he fights with me, he beats me and threatens me with a gun ...'

(Thula, 40)

Of the nine women who were victims of violence, only two defended themselves. They related their situations as follows:

'I ask him - what are you doing? Do you want to fight? And then I say to him if he wants to fight, let's fight and then I beat him too ...'

(Thembi, 39)

'I ran to the police station and I slept there. The next morning they came to catch my husband. They gave him a three-year sentence ...'

One of the women who did not protect herself stated:

'I did nothing. When I told my mother she said - you made the choice, he is your husband.'

(Lerato, 48)

Violence against women does not comprise merely physical incidents (Hegarty \& Roberts 2008:49). The United Nations, according to the World Health Organization (2008), defines violence against women as:

Any act of gender-based violence that results in, or is likely to result in, physical, sexual or mental harm or suffering to women, including threats of such acts, coercion or arbitrary deprivation of liberty, whether occurring in public or in private life.

(World Health Organization 2008)

Avoidance is one of the post-traumatic responses women experience when subjected to violence (Hou, Wang \& Chung 2003:353; Hou, Wang \& Chung 2005:633) and can even continue for years after the abusive relationship ends (Hou, Wang \& Chung 2003:355).

This study supports the findings of various surveys conducted on abuse of South African women (Wood, Jewkes \& Abrahams 1997; Dangor, Hoff \& Scott 1998; Jewkes, Levin \& Renn-Kekana 2002). According to Jewkes et al. (2002), the lifetime prevalence of experiencing physical violence from a current or previous husband or boyfriend is $24.6 \%$ for women in South Africa. Dangor et al. (1998), maintain that violence against women is due to the endemic culture of violence in South Africa, as well as customs, culture and tradition that change women into objects and male property. According to Goetz et al. (2008) the male mind might be designed to be hypersensitive to cues of sexual infidelity and is therefore prone to conclude, incorrectly, that infidelity has occurred. It seems that the most dangerous environment for a South African woman is the home she lives in (Okin 1998).

Alcohol abuse added to the difficulties of the respondents. Alcohol use was a problem in the lives of eight women and was also mentioned in relation to violence and sexual behaviour. Not only were women beaten when their partners were drunk, but the men also wanted unprotected sex. The following statements confirm this finding:

'He was a drunk ... he drinks a lot ... Especially when he was drunk he beat me ...'

(Thula, 40)

'When he drinks, he wants sex without a condom.'

(Ntombi, 53)

This finding supports the association between alcohol use and risky sexual behaviours like inconsistent condom use, sex

TABLE 4

Narratives of partners who did not refuse to use condoms and the reaction of the women 
exchange and multiple partners, which increases the sexual risk for women (Kalichman et al. 2006; Hutton et al. 2008).

The participants suffered financial hardship: Most of them were poor and had to rely on their partners for financial survival. The average income of the women who were sole breadwinners was R1780 per month, with an average of three dependents. Eight women expressed that they could not make ends meet and used their relationship as a survival strategy. Abdool-Karim (2001) reported the same phenomenon. Poverty is one of the reasons women hand sexual control over to men (Ankrah 1995; Kalichman et al. 2007; Kim \& Pronyk 2008). Food insufficiency was also found to be an important risk factor for increased sexual risk-taking among women (Weiser et al. 2007). One participant expressed lack of financial support as follows:

'He does not give me money ... some months only R300 to buy a small bag of maize meal ... not every month and for R300 you can buy nothing ...

(Thembi, 39)

Another explained:

'My husband used to pay the water and electricity, but for the past three months he paid nothing ... he says that he does not have money ... he earns about twice what I earn ...

(Sarah, 54)

Satisfaction with financial support was expressed as:

'My husband takes good care of me ...'

(Rosie, 30)

\section{Emotions}

Of the participants, 15 feared contracting a sexually transmitted infection (STI), most commonly AIDS. This fear is in contrast with the findings of Abdool-Karim (2001) who found that women in KwaZulu-Natal did not realise that they were at risk. Only one participant in this study did not discern her risk: Not only did she have two partners, she also preferred that her boyfriend did not use a condom during every sexual encounter.

One woman indicated that she had AIDS and had been infected by her partner with whom she had a long-standing relationship. A lack of trust in the fidelity of the partner was the reason participants feared being infected: 10 women did not trust their partners as they had proof of their infidelity and only four trusted their partners.

\section{Fear of infection was related as follows:}

'My husband, he wanted many women. Sometimes he did not sleep at home. Your husband comes home around twelve o' clock and then he wants to make sexy - but I see him together with another woman. Now I think that I must make the divorce - now I must stay alone - before I get sick. I found another woman with my husband. She had children with my husband. Now I say I do not want him anymore ... I said I want to leave him ... I do not want to get the sickness.

(Lily, 56)

'I don't want a disease because maybe I don't know if he has another girlfriend. You know how the men are cheating. I don't trust him.'

(Mapula, 33)

'I do not trust anyone -even if he has been my partner for so long. I have to play safe.'

(Masego, 40)

Fear of being exposed to STIs is described by Fischbach and Herbert (1997:1167) in their narration of the lived experience of a Kenyan woman after returning home from studying abroad. Hughes, Hoyo and Puoane (2006:434) also describe the fear of women in their observation that $36 \%$ of rural South African women feared contracting STIs from their returning migrant worker partners, yet almost none protected themselves and the $8 \%$ who used condoms used it for contraceptive purposes primarily. Chimbiri (2007:1110) found that concern about infection did not lead to a discussion of condom use in marriage.
Culturally defined gender roles in South Africa dictate that communication should occur from the man to the woman: Should a woman suggest using a condom, it is likely to lead to misunderstanding, conflict, suspicion of infidelity and violence (Maharaj 2001:158)

Fear of losing a partner also makes women reluctant to request condom use (Singer et al. 2006). This was also the case for the respondents in this study, and fear and helplessness were expressed:

'He will find another woman if I tell him he cannot have sex with me without using a condom ... So I give it ... what shall I do?'

(Beauty, 57)

Abu-Baker (2005) explains unsuccessful attempts to change a situation due to its size or lack of belief in the surrounding as being factors that lead to learned helplessness. Despite South Africa's constitution being built on human rights, a definite culture of masculinity exists and leads to a refusal to accept gender rights (Turfloop Law Week 2008). The perception of masculinity as well as defined gender roles -those of heterosexual success, power, dominance and the belief that women should be submissive limits communication and shared decision-making on sexual matters between partners (Maharaj 2001; Dunkle et al. 2007) and therefore denies women the right to protect themselves in their sexual relationship.

Eight participants experienced helplessness. Feeling helpless is not exceptional, considering the kind of relationships some women had. Helplessness, also called learned helplessness (Keeling 2004), is one of the characteristics of an abusive relationship (integritylifeskills.org S.A.) and was expressed by a respondent as follows:

If the man comes with the money, what are you going to do? You are going to say - take. You are not going to think about the condom ... you are going to see the money and you are going to say that he can take... You do not have power as you struggle to raise your children.

(Thembi, 39)

\section{ETHICAL CONSIDERATIONS}

The ethical principles as outlined in the Belmont Report (Polit \& Beck 2004), beneficence, respect of human dignity and justice, were followed by the interviewer in her invitation of the women to talk about self-protection in their sexual relationships. Informed consent was obtained from participants before the interviews. Anonymity and confidentiality were ensured by interviewing the women in private and using pseudonyms when transcribing the interviews. The views of participants were respected and time was allowed for them to raise queries. Furthermore, the research proposal was peer-reviewed by the Departmental and Faculty Research and Innovations Committees of the Tshwane University of Technology and approved by the Ethics Committee of the same university.

\section{TRUSTWORTHINESS}

Trustworthiness or the merit of qualitative enquiry (Krefting 1991:241) depends on four strategies: Credibility, transferability, dependability and confirmability. The strategies and criteria to enhance trustworthiness during data gathering and analysis are summarised in Table 1.

\section{LIMITATIONS OF THE STUDY}

The contextual nature of the study limited the application of the results to the community of Tshwane. Also, using a convenience snowball sample could lead to a sampling bias, as the participants were not independent of one another. The collation of data using self-reports could also lead to recall bias. The researcher's influence on the participants and perspective on the research topic could also have influenced the results of 
the study, however, this itself was limited by applying Parse's Theory of Human Becoming. No problems were experienced in undertaking the research and participants had the opportunity to be heard. One participant responded at the end of the interview:

'I feel much better. It was nice to be able to talk.'

(Annah, 49)

\section{RECOMMENDATIONS}

Primary prevention of cervical cancer is not a simple endeavour. Educational strategies should also target men, as they are key role players in the transmission of HPV. Primary prevention strategies should also focus on empowering women to protect themselves from cervical cancer and not to leave this important issue to others that might refuse it. This should improve women's access to recourses and advocacy for women's rights as equals. Female condoms should be introduced and made available to women to enable self-protection. All of these recommendations cannot be achieved without continuous support and counselling. Finally, the outcomes of primary prevention interventions should be evaluated continuously by means of research and improved according to the outcomes of evaluations. These suggestions may contribute to decreasing the numbers of women who die from a preventable, sexually transmitted cancer.

\section{CONCLUSION}

The study provided evidence that the participants were not able to protect themselves from cervical cancer by insisting on condom use. These women lacked knowledge about cervical cancer and therefore could not associate condom use with selfprotection against this disease. However, they did want their partners to use condoms as they did not trust them. Most of their partners refused to use condoms and when asked to do so, threatened, beat and accused their partners of being unfaithful. The respondents also experienced social problems because domestic violence, alcohol abuse and financial hardship were a reality for many of them. The subjects experienced fear and helplessness. For many, personal circumstances of poverty, physical abuse, helplessness and fear prevented them from insisting on condoms, even though they were aware of their partner's unfaithfulness.

\section{ACKNOWLEDGEMENTS}

This study was funded by the Research and Innovation Committee of the Adelaide Tambo School of Nursing Science at the Tshwane University of Technology, Tshwane, Gauteng.

\section{REFERENCES}

Abdool-Karim, Q., 2001, 'Barriers to preventing Human Immunodeficiency Virus in women: Experiences from KwaZulu-Natal, South Africa', Journal of the American Medical Women's Association 56(4), 193-196.

Abdullah, A., Fielding, R., Hedley, A., Ebrahim, S. \& Kuk, Y., 2002, 'Reasons for not using condoms among the Hong Kong Chinese population: Implications for HIV and STD prevention', Sexually Transmitted Infections 78, 180-184.

Abu-Baker, K., 2005, 'The impact of social values on the psychology of gender among Arab couples: A review from psychotherapy', The Israel Journal of Psychiatry and Related Science 42(2), 106-115.

Adesoji, A., 2005, 'Education: An antidote for the spread of HIV/ AIDS', Journal of the Association of Nurses in AIDS Care 16(2), 40-48.

Agha, S., Kusanthan, T., Longfield, K., Klein, M. \& Berman, J., 2002, 'Reasons for non-use of condoms in eight countries in sub-Saharan Africa', viewed 29 January 2009, from http//:www.psi.org/research/wp/WP49

Albertyn, C., 2003, 'Contesting democracy: HIV/AIDS and the achievement of gender equality in South Africa', Feminist studies 29(3), 595-615.
Ankrah, E., 1995, 'Let their voices be heard: Empowering women in the fight against AIDS', Aidscaptions 2(3), 4-7.

Brandhorst Krumboltz, H. \& Shapiro, J., 1979, 'Counseling women in behavioral self-direction', Personnel and Guidance Journal April, 415-418.

Burchell, A., Rachel, L., De Sanjose, S. \& Franco, E., 2006, 'Chapter 6: Epidemiology and transmission dynamics of genital HPV infection', Vaccine 24S3, S3/52-S3/61.

Burns, N. \& Grove, S., 2005, The practice of nursing research: Conduct, critique, and utilization, St. Louis, Elsevier.

CANSA, 2005, Cervical cancer, viewed 10 May 2007, from www. cansa.org.

Carter, M., Kraft, J., Koppenhaver, T., Galavotti, C., Roels, T., Kilmarx, P. \& Fidzani, B., 2007, 'A bull cannot be contained in a single kraal: Concurrent sexual partnerships in Botswana', AIDS Behaviour 11(6), 822-830.

Chimbiri, A., 2007, 'The condom is an "intruder" in marriage: Evidence from rural Malawi, Social Science and Medicine 64, 1102-1115.

Cothran, M. \& White, J., 2002, 'Adolescents' behavior and sexually transmitted diseases: The dilemma of human papillomavirus', Health Care Women International 23, 306-319.

Cresswell, J., 1994, Qualitative inquiry and research design: Choosing among five traditions, Sage, Thousand Oaks.

Dennis, P., 2006, 'The crisis of marriage in contemporary South Africa', Grace and Truth. A Journal of Catholic Reflection for Southern Africa 23(1), 3-8.

Denny, L., Quinn, M. \& Sankaranarayanan, R., 2006, 'Chapter 8: Screening for cervical cancer in developing countries', Vaccine 24(S3), S3/71-S73/77.

Dangor, Z., Hoff, L. \& Scott, R., 1998, 'Woman abuse in South Africa: An exploratory study', Violence Against Women 4, $125-152$.

Drumright, L., Gorbach, P. \& Holmes, K., 2004, 'Do people really know their sex partners? Concurrency, knowledge of partner behavior, and sexually transmitted infections within partnerships', Sexually Transmitted Diseases 31(7), 437-424.

Dunkle, K., Jewkes, R., Nduna, M., Jama, N., Levin, J., Sikweyiya, Y. \& Koss, M. 2007, 'Transactional sex with casual and main partners among young South African men in the rural Eastern Cape: Prevalence, predictors, and associations with gender-based violence', Social Science and Medicine 65, 1235-1248.

Epstein, R., 2005, 'Primary prevention of human papillomavirusneoplasia: No condom, no sex', European Journal of Cancer 41, 2595-6000.

Fischbach, R. \& Herbert B., 1997, 'Domestic violence and mental health: Correlates and conundrums within and across cultures', Social Science and Medicine 45(8), 1161-1176.

Frega, A., Stentella, P., De Ioris, A., Piazze, J., Frambini, M. Marchionni, M. \& Cosmi, E., 2003, 'Young women, cervical intraepithelial neoplasia and human papillomavirus: risk factors for persistence and recurrence', Cancer Letters 196, 127-134.

Gauteng Tourism Authority, SA, n.d., Did you know? Interesting facts about Gauteng, viewed 28 September 2009, from hppt: / / www.gauteng.net/index2.php?option +com_ content\&task=view\&id=170\&pop

Gavey, N., McPhillips, K. \& Doherty, M., 2001, 'If it's not on, it's not on - or is it?', Gender $\mathcal{E}$ Society 15(6), 917-934.

Goetz, A., Shackleford, T., Romeroa, G., Kaighobadi, F. \& Miner, E., 2008, 'Punishment, proprietariness, and paternity: Men's violence against women from an evolutionary perspective', Aggression and Violent Behavior 13, 481-489.

Gomo, E., Ndamba, J., Nhandara, C., Murahwa, S. \& Nyansema, N., 1997, 'Prevalence of gonorrhoea and knowledge of sexually transmitted infections in a farming community in Zimbabwe', The Central African Journal of Medicine 43(7), 192-195.

Hattori, M. \& Dodoo, F., 2007, 'Cohabitation, marriage and "sexual monogamy" in Nairobi's slums', Social Science and Medicine 64, 1067-1078.

Hawken, M., Melis, R., Ngombo, D., Mandaliya, K., Nganga, L., Price, J., Dallabetta, G. \& Temmerman, M., 2002, 'Sexual behaviour, knowledge and prevalence of sexually transmitted infections in a suburban community in Kenya', International Conference on AIDS, Barcelona, Spain, July 07-12, 2002, n.p. 
Hegarty, K. \& Roberts, G., 2008, 'How common is domestic violence against women? The definition of partner abuse in prevalence studies', Australian and New Zealand Journal of Public Health 22(1), 49-52.

Heysteck, M., De Jonge, E., Meyer, H. \& Lindeque, B., 1995, 'Screening for cervical neoplasia in Mamelodi -lessons from an unscreened population', South African Medical Journal 86(4), 1180-1182.

Holloway, I. \& Wheeler, S., 2002, Qualitative research in nursing, 2nd edn., Blackwell, Oxford.

Hou, W-L., Wang, H-H. \& Chung, H-H., 2003, 'Post-traumatic responses of abused women to marital violence', Kaohsiung Journal of Medical Sciences 19, 352-357.

Hou, W-L., Wang, H-H. \& Chung, H-H., 2005, 'Domestic violence against women in Taiwan: their life-threatening situations, post-traumatic responses, and psycho-physiological symptoms. An interview study', International Journal of Nursing Studies 42(6), 629-636.

Hughes, G., Hoyo, C. \& Puonane, T., 2006, 'Fear of sexually transmitted infections among women with male migrant partners - relationship to oscillatory migration pattern and risk-avoidance behavior', South African Medical Journal 96(5), 434-438.

Hutton, H. \& McCaul, M., 2008, 'The relationship between recent alcohol use and sexual behaviors: gender differences among sexually transmitted disease clinics partners', Alcoholism: Clinical and Experimental Research 32(11), 208-2011.

integritylifeskills.org., S.A., Seven red flags of abuse, viewed 06 February 2009, from http://www.integritylifeskills.org/ docs/sevenredflags.pdf

iolHIVAids.co.za, 2008, 'Understanding infidelity in Africa' viewed 29 January 2009, from http: / /www.iolhivaids.co.za/ index.php?from=rss IOL \%20Hiv-Aids\&fArticleID=4440335

Jewkes, R., Levin, R. \& Renn-Kekana, L., 2002, 'Risk factors for domestic violence: findings from a South African crosssectional study', Social Science E Medicine 55(9), 1603-1617.

Kalichman, S., Simbayi, L., Cain, D., Cherry, C., Jooste, S. \& Mathiti, V., 2006, 'Alcohol use and sexual risks for HIV/ AIDS in sub-Saharan Africa: systematic review of empirical findings', Prevention Science: the official journal of the Society for Prevention Research 8(2), 141-151.

Keeling, J., 2004, 'A community-based perspective of living with domestic violence', Nursing Times 100(11), 28-29.

Kim, J. \& Pronyk, P., 2008, 'Exploring the role of economic empowerment in HIV prevention', AIDS, suppl. 4, S57-S71.

Krefting, L., 1991, 'Rigor in qualitative research: the assessment of trustworthiness', American Journal of Occupational Therapy $45,214-222$

LoBiondo-Wood, G. \& Harber J., 2006, Nursing research: methods and critical appraisal for evidence-based practice, St Louis, Mosby.

Maharaj, P., 2001, 'Obstacles to negotiating dual protection: perspective of men and women', African Journal of Reproductive Health 5(3), 150-161.

Maharaj, P. \& Cleland, J., 2005, 'Risk perception and condom use among married and cohabiting couples in KwaZulu-Natal, South Africa', International Family Planning Perspectives 31(1), 24-29.

Mahon, S., 2009, 'Cancer epidemiology. Implications for prevention, early detection, and treatment', in S. Newton, M. Hickey \& J. Marrs (eds.), Mosby's oncology nursing advisor. A comprehensive guide to clinical practice, n.p., Mosby, St Louis.

Makua, T., 2008, 'Knowledge, hygiene and sexual practices of men contributing to the development of cervical cancer' Masters dissertation, Tshwane University of Technology.

Maree, J. \& Wright, S., 2007, 'Sexual and menstrual practices: risks for cervix cancer', Health SA Gesondheid 12(3), 55-65.

Mason, L., 2005, 'Knowledge of sexually transmitted infection and sources of information amongst men', The Journal of the Royal Society for the Promotion of Health 125(6), 266-271.

Mitchell, G., 2006, 'Parse's theory of human becoming in nursing practice', in M. Alligood \& A. Tomey (eds.), Nursing theory, utilization $\mathcal{E}$ application, n.p., Mosby, St Louis

Mnbaga, E., Leyna, G., Mnyika, K. \& Klepp, K., 2008 'Sexually transmitted infection knowledge and its impact in the practice of risky sexual behaviours and HIV serostatus: results from rural Kilimanjaro, Tanzania', Sexually Transmitted Infections $84,224-226$
Okin, S., 1998, 'Feminism, women's rights and cultural differences', Hypatia 13(2), 32-52

Oriel, J., 2005, 'Sexual pleasure as a human right: harmful of helpful to women in the context of HIV/AIDS?' Women's Studies International 28, 392-404.

Paranjape, A., Bernstein, L., St George, D., Doyle, J., Henderson, S. \& Gorbie-Smith, G., 2006 'Effect of relationship factors on safer sex decisions in older inner-city women', Journal of Womens Health 15(1), 90-97.

Parse, R., 1990, 'Health: a personal commitment', Nursing Science Quarterly 3, 136-140.

Parse, R., 1992, 'Human becoming: Parse's Theory of Nursing', Nursing Science Quarterly 5(1), 35-42.

Pillay, A., 2002, 'Rural and urban South African women's awareness of cancer of the breast and cervix', Ethnicity $\mathcal{E}$ Health 7(2), 103-114.

Polit, F. \& Beck, C., 2004, Nursing research: principles and methods, Lippincott, Philadelphia.

Randolph, M., Pinkerton, S., Bogard, 1., Cecil, H., \& Abrahamson, P., 2007, 'Sexual pleasure and condom use', Archives of Sexual Behavior 36(6), 844-848.

Schiffman, M., Philip E., Jeronimo J., Rodriques A. \& Wacholder S., 2007, 'Human papillomavirus and cervical cancer', Lancet 370, 890-907.

Senn, T., Carey, M., Vanable, P., Coury-Doniger, P. \& Urban, M. 2009, 'Sexual partner concurrency among STI clinic patients with a steady partner: correlates and associations with condom use', Sexually Transmitted Infections 85(5), 343-347.

Singer, M., Erickson, P., Badiane, L., Diaz, R., Ortiz, D., Abraham, T. \& Nicolaysen, A., 2006, 'Syndemics, sex and the city: understanding sexually transmitted disease in social and cultural context', Social Science and Medicine 63(8), 2010-2021.

South African Medical Research Council, 2008, Our research viewed 10 May 2006, from http://www.mrc.ac.za/bod/ faqcancer.htm

Stark, A.M. \& Hope, A., 2007, 'Aboriginal women's stories of sexually transmissible infection transmission and condom use in remote central Australia', Sexual Health 4(4), 237-242.

Steiner, M., Cates, W. \& Warner, L., 1999, 'The real problem with male condoms is nonuse', Sexually Transmitted Diseases 26(8) $459-462$.

Talbot, L., 1995, Principles and practice of nursing research, Mosby, Boston.

Turfloop Law Week, 2008, 'Obstacles to gender equity', Limpopo Leader 15, 12-13.

Verhoeven, V., Baay, M., Colliers, A., Verster, A., Van Royen, P., Avonts, D. \& Vermorken, J., 2006, 'The male factor in cervical carcinogenesis: a questionnaire study of men's awareness in primary care', Preventative Medicine 43, 389-393.

Welman, J. \& Kruger, S., 1999, Research methodology for the business and administrative sciences, Oxford University Press, Oxford.

Weiser, S., Leiter, K., Bangsberg, D., Butler, L., Percy-de Korte, F., Hlanze, Z., Phaladze, N., Iacopino, V. \& Heisler, M. 2007, 'Food insufficiency is associated with high-risk sexual behavior among women in Botswana and Swaziland', PLOS Medicine 4(10), 1589-1598.

Williamson, N., Liku, J., McLoughlin, K., Nyamongo, I. \& Nakayima, F., 2006, 'A qualitative study of condom use among married couples in Kampala, Uganda', Reproductive Health Matters 14(28), 89-98.

Wood, K., Jewkes, R. \& Abrahams, N., 1997, 'Cleaning the womb: constructions of cervical screening and womb cancer among rural black women in South Africa', Social Science $\mathcal{E}$ Medicine 45(2), 283-294.

Woodsong, C., Koo, H., 1999, 'Two good reasons: women's and men's perspectives on dual contraceptive use', Social Science and Medicine 49(5), 567-580.

World Health Organization and International Union Against Cancer, 2005, Global action against cancer, WHO and IUAC, Switzerland.

World Health Organization, 2008, Violence against women, Fact Sheet 239ed, viewed 19 September 2009, from http:/ / www. who.int/mediacentre/factsheets.fs239/en/print.html 